\title{
Effects of Aminoethoxyvinylglycine Plus 1-Methylcyclopropene on 'Royal Gala' Apple Volatile Production After Cold Storage
}

\author{
Valeria Sigal Escalada ${ }^{1}$ \\ Department of Horticulture, University of Kentucky, Lexington, \\ KY 40546-0091
}

\author{
Douglas D. Archbold ${ }^{2,3}$ \\ Department of Horticulture, University of Kentucky, Lexington, \\ KY 40546-0091
}

Additional index words. aminoethoxyvinylglycine, 1-methylcyclopropene, postharvest, flavor

\begin{abstract}
Both aminoethoxyvinylglycine (AVG) and 1-methylcyclopropene (1-MCP) are useful tools for managing apple fruit ripening, and their impacts on apple volatile production have been independently assessed. In this work, their combined effect, as might occur in commercial production and postharvest storage, on 'Royal Gala' apple volatile production at harvest and after air storage was compared with the effect of each alone. An aqueous solution of AVG was applied to 'Royal Gala' apple trees 4 weeks before the normal harvest date (H1) at $124 \mathrm{~g} \cdot \mathrm{ha}^{-1} / \mathrm{a} . \mathrm{i}$. in 2004 and 2005 . Control and AVG-treated fruit were treated at $\mathrm{H} 1$ or after harvest of AVG fruit 2 weeks later (H2) for $20 \mathrm{~h}$ at $30^{\circ} \mathrm{C}$ with $1-\mathrm{MCP}$ at a final headspace concentration of $1 \mu \mathrm{L} \cdot \mathrm{L}^{-1}$. Fruit were ripened for $7 \mathrm{~d}$ at room temperature immediately after harvest and treatment or after treatment and then cold storage at $4{ }^{\circ} \mathrm{C}$ for 6 or 12 weeks. Peel and cortex tissue of control and AVG plus 1-MCP-treated fruit was provided with butanol or hexanol and ester production was quantified. The combination of AVG plus 1-MCP was more effective in reducing internal ethylene concentration than either alone. Both total volatile production and that of the major individual esters, including hexyl acetate, butyl acetate, and 2-methylbutylacetate, which are considered key constituents of 'Gala' aroma, were consistently repressed by the combination of AVG plus 1-MCP after harvest and up to 12 weeks of cold storage. The effects of AVG plus 1-MCP were evident even with $\mathrm{H} 2$ fruit when the effects of AVG alone on fruit ripening were at least partially lost. Because alcohol-acyl transferase activity was unaffected by AVG plus 1-MCP, AVG plus 1-MCPtreated peel and cortex samples had similar total ester production when they were provided butanol or hexanol. Total alcohols showed recovery in most treatments except AVG plus 1-MCP, so precursor availability was likely the major factor limiting ester production. The results indicated a sustained adverse effect of the AVG plus 1-MCP treatment on aroma volatile production that could impact consumer acceptability.
\end{abstract}

Techniques that stop premature fruit drop and slow ripening of climacteric fruit are valuable to growers, shippers, and retailers, permitting efficient harvest and orderly marketing. Aminoethoxyvinylglycine (AVG) is commercially used to stop apple (Malus $\times$ domestica Borkh.) fruit drop with application 1 month before harvest (Drake et al., 2005, 2006; Greene, 2006; Greene and Schupp, 2004; Schupp and Greene, 2004). The compound acts by blocking ethylene biosynthesis. Postharvest use of 1-methylcyclopropene (1-MCP), which binds to ethylene receptors and

Received for publication 19 Feb. 2009. Accepted for publication 15 May 2009

We thank Randall W. Collins for his assistance with aroma volatile analyses.

${ }^{1}$ Former Graduate Student.

${ }^{2}$ Professor of Horticulture

${ }^{3}$ To whom reprint requests should be addressed; e-maildarchbol@uky.edu. blocks a response to the phytohormone, can significantly delay apple ripening (DeLong et al., 2004; Fan et al., 1999; Ferenczi et al., 2006; Mattheis et al., 2005; Moya-Leon et al., 2007; Rupasinghe et al., 2000). These compounds are commonly used along with cold storage to manage apple fruit ripening.

Several quality factors influence the acceptability of apples, including appearance, texture, and flavor. Flavor is a complex trait composed of sweetness, sourness, bitterness, saltiness, and aroma; the mix of sugars, acids, and volatile compounds play a primary role in quality composition (Baldwin, 2002). Aroma volatile compounds produced by apple fruit include esters, alcohols, aldehydes, acids, ketones, and terpenes (Fan and Mattheis, 1999; Lurie et al., 2002). The majority of the volatiles are esters ( $78 \%$ to $82 \%$ ) and alcohols (6\% to $16 \%)$, and the most abundant are evennumbered 2 to 6 carbon chains (Paillard, 1990). The changes in volatile production during ripening result from an increase in ester production that is regulated by ethylene (Fan and Mattheis, 1999). Ester synthesis involves the transfer of acyl moieties to alcohols from acyl-CoAs. This step, catalyzed by the enzyme alcohol-acyl transferase (AAT), is regulated by ethylene through an induction in transcription of $A A T$ (Defilippi et al., 2005a; Fan and Mattheis, 1999). However, Echeverria et al. (2004) found that precursor availability is a more significant factor overall than enzyme activity for the development of aroma during on-tree maturation of 'Fuji' apples.

Cold storage alone can alter aroma volatile production (Plotto et al., 2000). In addition, AVG inhibited ethylene and volatile production (Bangerth and Streif, 1987; Fan et al., 1998; Halder-Doll and Bangerth, 1987; Mir et al., 1999), and 1-MCP reduced total volatile production of several apple cultivars after treatment or cold storage (Ferenczi et al., 2006; Kondo et al., 2005; Lurie et al., 2002; Rupasinghe et al., 2000). Thus, apple flavor can be altered by these common practices, and it is possible that these compounds may be used together along with cold storage. When used in combination as preand postharvest applications, respectively, AVG plus 1-MCP effects have been inconsistent, improving fruit firmness after cold storage more than either alone in some but not all studies (Argenta et al., 2006; Drake et al., 2006; Moran, 2006; Robinson et al., 2006). Although there is information about the effects of the chemicals individually and combined on some apple ripening traits, there have been no reports about their combined effects on aroma volatile production. Because fruit flavor is integral to consumer acceptability, and aroma volatile production is sensitive to ethylene levels, understanding the potential interaction of $\mathrm{AVG}$ and 1-MCP is essential to their effective use and to avoiding possible adverse consequences. Thus, the objectives of this study were to assess the effects of AVG plus 1-MCP on 'Royal Gala' apple aroma volatile production at harvest and after short-term cold storage.

\section{Materials and Methods}

Treatments and harvest. In 2004 and 2005, eight trees of 'Royal Gala/M7a', planted in 1993 at the University of Kentucky Horticultural Research Farm in Lexington, $\mathrm{KY}$, and maintained following standard commercial horticultural practices for the region, were selected. Four of the trees, one per row and none adjacent to one another or to control trees, were treated with an aqueous solution of AVG (ReTain; Valent Biosciences, Libertyville, IL) containing $500 \mu \mathrm{L} \cdot \mathrm{L}^{-1}$ Silwet L-77 (Helena Chemical Co., Collierville, TN) as surfactant 4 weeks before the expected normal harvest at the commercial rate of 124 g/a.i./ha (Commercial Tree Fruit Spray Guide, 2006), and four trees were not treated (controls). The AVG was applied to leaves and fruit with a hand pump sprayer to the point of runoff. Control fruit were harvested at the beginning of ripening (H1) based on starch 
index and ethylene production, at $119 \mathrm{~d}$ after full bloom (DAFB) in 2004 and 123 DAFB in 2005. AVG-treated apples were harvested with the control fruit (H1) and were also harvested 2 weeks later (H2) in 2004 (133 DAFB) and 1 week later in 2005 (130 DAFB).

After harvest, fruit were allowed to equilibrate at ambient laboratory temperature $(21 \pm$ $\left.0.5^{\circ} \mathrm{C}\right)$ for 3 to $5 \mathrm{~h}$. Half of each lot $(\approx 150$ fruit) was then placed in $26-\mathrm{L}$ plastic containers for $20 \mathrm{~h}$ with 1-MCP (EthylBloc powder, $0.14 \%$ a.i.; Biotechnologies for Horticulture, Burr Ridge, IL) in a solution at $\mathrm{pH} 8.2$ to produce an estimated final headspace 1-MCP concentration of $1 \mu \mathrm{L} \cdot \mathrm{L}^{-1}$. There were four treatments at $\mathrm{H} 1$ (control, AVG, 1-MCP, and AVG plus 1-MCP) and two treatments at $\mathrm{H} 2$ (AVG and AVG plus 1-MCP). Fruit were ripened at $21{ }^{\circ} \mathrm{C}$ for $7 \mathrm{~d}$ after postharvest treatment or were stored in cold storage for 6 or 12 weeks at $4{ }^{\circ} \mathrm{C}$ and later ripened at $21^{\circ} \mathrm{C}$ for $7 \mathrm{~d}$.

Internal ethylene concentration. Internal ethylene concentration (IEC) was measured on 10 fruit per treatment on Days 1 and 7 after harvest or 6 or 12 weeks of cold storage. A gas sample was taken from the seed cavity by inserting a needle attached to a $10-\mathrm{mL}$ syringe through the calyx end, and a $0.2-\mathrm{mL}$ subsample was analyzed by gas chromatography (HP 5890; Agilent Technologies, Wilmington, DE) equipped with a flame ionization detector (FID) and an alumina capillary column (AT-Alumina Plot GC Column, $30 \mathrm{~m}, 0.53 \mathrm{~cm}$ i.d.) containing activated alumina using $\mathrm{N}_{2}$ as the carrier gas. Temperatures were 35,175 , and $125{ }^{\circ} \mathrm{C}$ for oven, injector, and FID, respectively. An external standard $\left(100 \mu \mathrm{L} \cdot \mathrm{L}^{-1}\right.$ ethylene/helium; Alltech Associates Inc., Deerfield, IL) was diluted and used to quantify the amounts of ethylene.

Fruit tissue sampling. At $7 \mathrm{~d}$ after harvest or removal from 6 or 12 weeks of cold storage, the apples used for ethylene analyses were sectioned into peel and cortex, and tissue samples were frozen and stored at $-80{ }^{\circ} \mathrm{C}$. For analysis of volatile production and AAT activity, composite peel and cortex samples were derived from three fruit. There were three replications of composite samples for each treatment and storage period.

Aroma volatile analyses. Headspace volatile production was measured on three $\approx 9 \mathrm{~g}$ peel and three $\approx 9$ g cortex composite samples per treatment after thawing as described in Hamilton-Kemp et al. (2003). Volatiles were identified from retention times matching those of authentic standards.

Alcohol acyl-CoA transferase activity. Alcohol acyl-CoA transferase activity was separately assayed on peel and cortex tissue of three 3-g composite samples per treatment, each composite from three apples. Tissues were frozen at $-80{ }^{\circ} \mathrm{C} 7 \mathrm{~d}$ after harvest or removal from 6 or 12 weeks of cold storage and were later analyzed using a method described by Echeverria et al. (2004). AAT activity was expressed as $\mathrm{mU} \cdot \mathrm{mg}$ protein $^{-1}$ in which a unit (U) of activity is the increase in one unit of absorbance per minute. Total

Table 1. Internal ethylene concentration of 'Royal Gala' fruit in 2004 and $2005 .{ }^{\mathrm{z}}$

\begin{tabular}{|c|c|c|c|c|c|c|}
\hline \multirow[b]{3}{*}{ Treatment } & \multicolumn{6}{|c|}{ Internal ethylene concn $\left(\mu \mathrm{L} \cdot \mathrm{L}^{-1}\right)$} \\
\hline & \multicolumn{3}{|c|}{2004} & \multicolumn{3}{|c|}{2005} \\
\hline & Harvest & 6 weeks & 12 weeks & Harvest & 6 weeks & 12 weeks \\
\hline Control & 6 & 0 & 0 & 9 & 96 & 173 \\
\hline AVG & 0 & 3 & 1 & 6 & 44 & 71 \\
\hline 1-MCP & 1 & 2 & 21 & 1 & 1 & 4 \\
\hline $\mathrm{AVG}+1-\mathrm{MCP}$ & 0 & 2 & 0 & 0 & 0 & 2 \\
\hline AVG H2 & 5 & 27 & 28 & 11 & 72 & 10 \\
\hline $\mathrm{AVG}+1-\mathrm{MCP} \mathrm{H} 2$ & 0 & 1 & 1 & 0 & 6 & 1 \\
\hline$\underline{\text { LSD }}$ & 2 & 9 & 11 & 10 & 49 & 111 \\
\hline
\end{tabular}

${ }^{\mathrm{z}}$ Fruit were treated with aminoethoxyvinylglycine (AVG) 1 month before harvest and/or 1methylcyclopropene (1-MCP) immediately after harvest and ripened for $7 \mathrm{~d}$ at $21{ }^{\circ} \mathrm{C}$ after harvest or after $4{ }^{\circ} \mathrm{C}$ storage for 6 or 12 weeks. Ethylene was measured after $7 \mathrm{~d}$. AVG-treated fruit were harvested with controls and 1 to 2 weeks later (H2). Fisher's least significant difference (LSD) at $P=0.05$ is shown to compare means.

Table 2. Total volatile esters and alcohols produced by peel and cortex tissue from 'Royal Gala' fruit in 2004 and $2005 .^{\mathrm{z}}$

\begin{tabular}{|c|c|c|c|c|c|c|c|}
\hline & \multicolumn{7}{|c|}{$\mathrm{AU} \times 10^{-3}$ per $\mathrm{g}$ fresh weight } \\
\hline & \multirow[b]{2}{*}{ Treatment } & \multicolumn{2}{|c|}{ Harvest } & \multicolumn{2}{|c|}{6 weeks } & \multicolumn{2}{|c|}{12 weeks } \\
\hline & & Peel & Cortex & Peel & Cortex & Peel & Cortex \\
\hline & \multicolumn{7}{|c|}{2004} \\
\hline \multirow[t]{7}{*}{ Total esters } & Control & 2,207 & 979 & 722 & 286 & 677 & 246 \\
\hline & AVG & 971 & 795 & 1,620 & 705 & 1,846 & 619 \\
\hline & 1-MCP & 1,149 & 697 & 2,185 & 1,052 & 2,794 & 1,738 \\
\hline & $\mathrm{AVG}+1-\mathrm{MCP}$ & 362 & 143 & 736 & 336 & 691 & 275 \\
\hline & AVG H2 & 1,598 & 1,024 & 2,553 & 1,189 & 2,540 & 1,230 \\
\hline & $\mathrm{AVG}+1-\mathrm{MCP} \mathrm{H} 2$ & 527 & 306 & 669 & 318 & 633 & 265 \\
\hline & LSD & 604 & 216 & 957 & 460 & 647 & 487 \\
\hline \multirow[t]{8}{*}{ Total alcohols } & Control & 51 & 51 & 19 & 16 & 18 & 19 \\
\hline & AVG & 2 & 2 & 15 & 13 & 31 & 24 \\
\hline & 1-MCP & 16 & 16 & 36 & 40 & 62 & 63 \\
\hline & $\mathrm{AVG}+1-\mathrm{MCP}$ & 1 & 1 & 4 & 3 & 3 & 2 \\
\hline & AVG H2 & 23 & 24 & 64 & 46 & 82 & 71 \\
\hline & $\mathrm{AVG}+1-\mathrm{MCP} \mathrm{H} 2$ & 2 & 2 & 23 & 10 & 3 & 3 \\
\hline & LSD & 10 & 4 & 33 & 26 & 21 & 19 \\
\hline & \multicolumn{7}{|c|}{2005} \\
\hline \multirow[t]{7}{*}{ Total esters } & Control & 2,813 & 1,544 & 2,911 & 1,915 & 5,569 & 3,386 \\
\hline & AVG & 1,691 & 992 & 1,751 & 1,068 & 5,376 & 3,128 \\
\hline & 1-MCP & 836 & 521 & 490 & 189 & 1,523 & 535 \\
\hline & $\mathrm{AVG}+1-\mathrm{MCP}$ & 565 & 344 & 407 & 166 & 1,306 & 1,936 \\
\hline & AVG H2 & 1,940 & 839 & 2,357 & 1,027 & 4,350 & 2,320 \\
\hline & $\mathrm{AVG}+1-\mathrm{MCP} \mathrm{H} 2$ & 569 & 335 & 361 & 514 & 756 & 273 \\
\hline & LSD & 741 & 271 & 461 & 496 & 1,017 & 1,026 \\
\hline \multirow[t]{7}{*}{ Total alcohols } & Control & 21 & 22 & 53 & 31 & 200 & 89 \\
\hline & AVG & 12 & 9 & 33 & 23 & 189 & 85 \\
\hline & 1-MCP & 2 & 2 & 6 & 6 & 35 & 26 \\
\hline & $\mathrm{AVG}+1-\mathrm{MCP}$ & 0 & 1 & 4 & 5 & 30 & 22 \\
\hline & AVG H2 & 32 & 24 & 61 & 35 & 174 & 52 \\
\hline & AVG + 1-MCP H2 & 2 & 2 & 1 & 5 & 21 & 18 \\
\hline & LSD & 10 & 7 & 6 & 7 & 54 & 17 \\
\hline
\end{tabular}

${ }^{\mathrm{z}}$ Fruit were treated with aminoethoxyvinylglycine (AVG) 1 month before harvest and/or 1methylcyclopropene (1-MCP) immediately after harvest and ripened for $7 \mathrm{~d}$ at $21{ }^{\circ} \mathrm{C}$ after harvest or after $4{ }^{\circ} \mathrm{C}$ storage for 6 or 12 weeks. AVG-treated fruit were harvested with controls and 1 to 2 weeks later (H2). Fisher's least significant difference (LSD) at $P=0.05$ is shown to compare means.

protein content of the enzyme extract was determined spectrophotometrically at 595 nm using the Coomassie Plus ${ }^{\mathrm{TM}}$ Protein Assay Kit (Pierce, Rockford, IL) following the manufacturer's instructions and using bovine serum albumin (Fisher Scientific, Fair Lawn, NJ) as a standard.

Volatile substrate supplied. Alcohol substrates were separately provided in the headspace to apple peel and cortex tissues to assess capacity for volatile synthesis. The experiment was conducted in 2005 using control and AVG plus 1-MCP-treated fruit stored for 12 weeks at $4{ }^{\circ} \mathrm{C}$. Fruit from storage were equilibrated at $21{ }^{\circ} \mathrm{C}$ for $3 \mathrm{~h}$.
Peel strips (10 to $12 \mathrm{~mm}$ wide) and cortex plugs ( $5 \mathrm{~mm}$ diameter, 50 to $80 \mathrm{~mm}$ length) were combined into nine separate $3-\mathrm{g}$ composite samples, each composite from three fruit, per treatment and tissue type. All samples were placed on three layers of water-saturated filter paper in $15-\mathrm{mL}$ glass jars sealed with Teflon-lined plastic screw caps. Three samples per treatment and tissue type were provided with $5 \mu \mathrm{L}$ of 1-butanol or 1-hexanol (Fisher Scientific), and three samples not provided an alcohol were used as controls. Alcohol substrates were placed in small open glass containers inside the glass jars and allowed to evaporate to be available 


\begin{tabular}{|c|c|c|c|c|c|c|c|}
\hline \multirow{2}{*}{ Compound } & \multirow{2}{*}{ Treatment } & \multicolumn{6}{|c|}{$\mathrm{AU} \times 10^{-3}$ per $\mathrm{g}$ fresh weight } \\
\hline & & \multicolumn{2}{|c|}{ Harvest } & \multicolumn{2}{|c|}{6 weeks } & \multicolumn{2}{|c|}{12 weeks } \\
\hline \multirow[t]{5}{*}{ Ethyl-2-methyl butanoate } & Control & 490 & 614 & 302 & 2,383 & 225 & 371 \\
\hline & $1-\mathrm{MCP}$ & 287 & 381 & 428 & 164 & 399 & 296 \\
\hline & $\mathrm{AVG}+1-\mathrm{MCP}$ & 175 & 304 & 465 & 165 & 431 & 352 \\
\hline & AVG H2 & 367 & 362 & 339 & 198 & 337 & 304 \\
\hline & $\mathrm{AVG}+1-\mathrm{MCP} \mathrm{H} 2$ & 252 & 270 & 337 & 150 & 345 & 253 \\
\hline \multirow{6}{*}{ 2-Methylbutyl acetate } & AVG & 3 & 141 & 61 & 227 & 105 & 784 \\
\hline & $1-\mathrm{MCP}$ & 191 & 131 & 162 & 47 & 243 & 203 \\
\hline & $\mathrm{AVG}+1-\mathrm{MCP}$ & 5 & 46 & 10 & 39 & 7 & 153 \\
\hline & AVG H2 & 122 & 281 & 188 & 238 & 208 & 363 \\
\hline & $\mathrm{AVG}+1-\mathrm{MCP} \mathrm{H} 2$ & 59 & 85 & 31 & 37 & 9 & 625 \\
\hline & LSD & 102 & 153 & 125 & 69 & 86 & 216 \\
\hline \multirow{3}{*}{ Ethyl butanoate } & Control & 299 & 498 & 212 & 227 & 228 & 313 \\
\hline & $\mathrm{AVG}+1-\mathrm{MCP} \mathrm{H} 2$ & 150 & 130 & 223 & 89 & 254 & 121 \\
\hline & LSD & 109 & 81 & 145 & 37 & 85 & 68 \\
\hline \multirow{7}{*}{ Butyl acetate } & Control & 190 & 190 & 29 & 295 & 35 & 840 \\
\hline & AVG & 2 & 75 & 35 & 153 & 79 & 521 \\
\hline & 1-MCP & 44 & 17 & 206 & 25 & 376 & 72 \\
\hline & $\mathrm{AVG}+1-\mathrm{MCP}$ & 0 & 4 & 2 & 18 & 1 & 57 \\
\hline & AVG H2 & 75 & 114 & 219 & 240 & 290 & 422 \\
\hline & $\mathrm{AVG}+1-\mathrm{MCP} \mathrm{H} 2$ & 7 & 13 & 19 & 14 & 2 & 27 \\
\hline & LSD & 53 & 99 & 162 & 70 & 121 & 109 \\
\hline \multirow[t]{5}{*}{ Butyl hexanoate } & Control & 214 & 360 & 28 & 348 & 52 & 698 \\
\hline & AVG & 2 & 122 & 80 & 224 & 160 & 768 \\
\hline & 1-MCP & 41 & 18 & 169 & 32 & 227 & 315 \\
\hline & $\mathrm{AVG}+1-\mathrm{MCP}$ & 1 & 7 & 3 & 22 & 3 & 210 \\
\hline & AVG H2 & 115 & 232 & 258 & 306 & 302 & 650 \\
\hline
\end{tabular}

${ }^{\mathrm{z}}$ Fruit were treated with aminoethoxyvinylglycine (AVG) 1 month before harvest and/or 1-methylcyclopropene (1-MCP) immediately after harvest and ripened for $7 \mathrm{~d}$ at $21^{\circ} \mathrm{C}$ after harvest or after $4{ }^{\circ} \mathrm{C}$ storage for 6 or 12 weeks. AVG-treated fruit were harvested with controls and 1 to 2 weeks later (H2). Fisher's least significant difference (LSD) at $P=0.05$ is shown to compare means.

for tissue uptake. The sealed containers were placed in an incubator at $22{ }^{\circ} \mathrm{C}$ for $24 \mathrm{~h}$. Samples were then frozen at $-20{ }^{\circ} \mathrm{C}$. For volatile analysis, samples were thawed in 15 $\mathrm{mL}$ glass jars sealed with Teflon-lined plastic screw caps containing a three-layer septum. Samples were equilibrated in a water bath to $26^{\circ} \mathrm{C}$ for $2 \mathrm{~h}$ and then placed at $21^{\circ} \mathrm{C}$. Headspace volatiles were sampled as described previously.

Experimental design and statistical analysis. Each experiment was conducted using a completely random design. All data were subjected to analysis of variance, and means were compared by Fisher's protected least significance difference $(P=0.05)$ using SAS Version 9.1 software (SAS Institute Inc., Cary, NC).

\section{Results and Discussion}

Internal ethylene concentration. Control fruit had an IEC close to $1 \mu \mathrm{L} \cdot \mathrm{L}^{-1} 1 \mathrm{~d}$ after harvest both years, whereas all treated fruit had a lower IEC (data not shown). After $7 \mathrm{~d}$ at $21{ }^{\circ} \mathrm{C}$, only control fruit and AVG-treated fruit from $\mathrm{H} 2$ had IEC values higher than $1 \mu \mathrm{L} \cdot \mathrm{L}^{-1}$ in 2004 , whereas control and AVGtreated apples from both $\mathrm{H} 1$ and $\mathrm{H} 2$ had IEC values over $1 \mu \mathrm{L} \cdot \mathrm{L}^{-1}$ in 2005 (Table 1). IEC of fruit treated with 1-MCP or AVG plus 1MCP was low both years. After 6 weeks of cold storage in 2004, AVG-treated fruit from $\mathrm{H} 2$ had the highest IEC, and controls and all other treatments from both harvests had low IEC values. In 2005, control and AVGtreated fruit from $\mathrm{H} 1$ and $\mathrm{H} 2$ had high IECs, whereas values for the other treatments were lower than controls. After 12 weeks of cold storage in 2004, 1-MCP- and AVG-treated fruit from $\mathrm{H} 2$ had the highest IEC. In 2005, control fruit had a higher IEC than any treatment other than AVG from H1. Overall, AVG plus 1-MCP consistently resulted in a low, or the lowest, IEC independent of harvest date and cold storage length. The effects of 1-MCP in 2004, AVG at H1 in 2005, and AVG at H2 both years may have been diminishing during cold storage as their IEC values increased.

Aroma volatile production. Total volatile ester and alcohol production were derived from the sum of the area units of the identified ester and alcohol volatile compounds, including the esters (in descending order by amount from control fruit at harvest): ethyl2-methylbutanoate, hexyl acetate, ethyl butanoate, 2-methylbutylacetate, butyl hexanoate, butyl acetate, hexyl hexanoate, hexyl 2-methylbutanoate, butyl 2-methylbutanoate, and butyl butanoate; and the alcohols: hexanol, 1-butanol, and 2-methyl-1-butanol. The total ester production by peel tissue of untreated control fruit was higher than that by cortex tissue both seasons (Table 2), but trends of controls over storage time differed between years. In 2004, total ester production of both tissues decreased over time in cold storage (peel total $=2301.4-385.7 \mathrm{x}+21 \mathrm{x}^{2}, R^{2}=0.94$, $P<0.01$; cortex total $=1024.2-177.7 \mathrm{x}+$ $9.5 \mathrm{x}^{2}, R^{2}=0.89, P<0.01 ; \mathrm{x}$ is time in months; $\mathrm{n}=9$ ). In 2005 , total ester production of 
Table 4. Alcohol-acyl transferase activity of peel and cortex tissue from 'Royal Gala' fruit in 2004 and 2005. ${ }^{\mathrm{z}}$

\begin{tabular}{|c|c|c|c|c|c|c|}
\hline \multirow[b]{3}{*}{ Treatment } & \multicolumn{6}{|c|}{$\mathrm{mU} \cdot \mathrm{mg}^{-1}$ protein } \\
\hline & \multicolumn{2}{|c|}{ Harvest } & \multicolumn{2}{|c|}{6 weeks } & \multicolumn{2}{|c|}{12 weeks } \\
\hline & $\overline{\text { Peel }}$ & $\overline{\text { Cortex }}$ & Peel & $\overline{\text { Cortex }}$ & Peel & Cortex \\
\hline & \multicolumn{6}{|c|}{2004} \\
\hline Control & 162 & 151 & 191 & 126 & 178 & 121 \\
\hline AVG & 110 & 113 & 111 & 172 & 112 & 172 \\
\hline 1-MCP & 112 & 100 & 117 & 124 & 109 & 114 \\
\hline $\mathrm{AVG}+1-\mathrm{MCP}$ & 111 & 107 & 160 & 118 & 127 & 115 \\
\hline AVG H2 & 114 & 135 & 119 & 136 & 149 & 198 \\
\hline $\mathrm{AVG}+1-\mathrm{MCP} \mathrm{H} 2$ & 120 & 119 & 98 & 141 & 89 & 137 \\
\hline \multirow[t]{2}{*}{ LSD } & 31 & NS & 26 & NS & 32 & 37 \\
\hline & \multicolumn{6}{|c|}{2005} \\
\hline Control & 139 & 162 & 159 & 135 & 121 & 157 \\
\hline AVG & 133 & 128 & 140 & 120 & 172 & 160 \\
\hline 1-MCP & 124 & 140 & 137 & 123 & 114 & 149 \\
\hline $\mathrm{AVG}+1-\mathrm{MCP}$ & 125 & 122 & 145 & 148 & 115 & 140 \\
\hline AVG H2 & 143 & 161 & 168 & 178 & 198 & 160 \\
\hline $\mathrm{AVG}+1-\mathrm{MCP} \mathrm{H} 2$ & 127 & 146 & 149 & 144 & 137 & 147 \\
\hline LSD & NS & 26 & 24 & 47 & 37 & NS \\
\hline
\end{tabular}

${ }^{\mathrm{z}}$ Fruit were treated with aminoethoxyvinylglycine (AVG) 1 month before harvest and/or 1methylcyclopropene (1-MCP) immediately after harvest and ripened for $7 \mathrm{~d}$ at $21{ }^{\circ} \mathrm{C}$ after harvest or after $4{ }^{\circ} \mathrm{C}$ storage for 6 or 12 weeks. AVG-treated fruit were harvested with controls and 1 to 2 weeks later (H2). Fisher's least significant difference (LSD) at $P=0.05$; ns indicates nonsignificant difference among treatments.

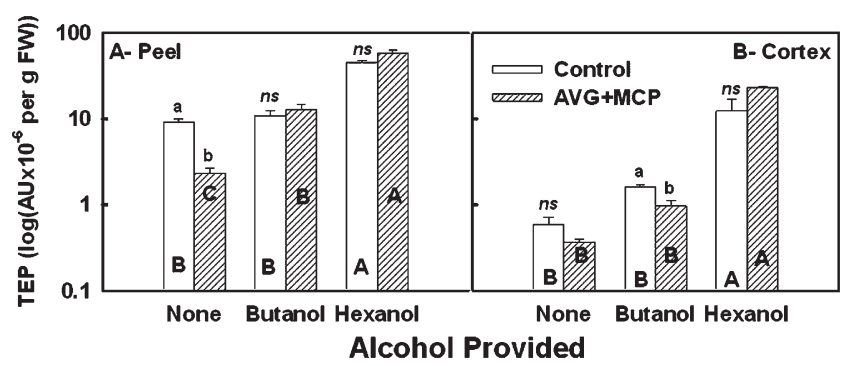

Fig. 1. Total ester production (TEP) by peel (A) and cortex (B) of 'Royal Gala' apples provided with alcohol substrates. Peel and cortex tissue of fruit that had been stored for 12 weeks at $4{ }^{\circ} \mathrm{C}$ were incubated with no alcohol (control), 1-butanol, or 1-hexanol for $24 \mathrm{~h}$, and volatile ester profiles were subsequently measured. Different lower case letters indicate significant differences between control and aminoethoxyvinylglycine (AVG) plus 1-methylcyclopropene (1-MCP) peel or cortex tissue within alcohol substrate separated by least significant difference (LSD) at $P=0.05$; different upper case letters indicate significant differences among alcohol substrates categories within tissue type and treatment (control or AVG plus 1-MCP) separated by LSD at $P=0.05$ within date. $n s=$ no significant difference.

both tissues increased over time in cold storage (peel total $=2874.5-196.6 \mathrm{x}+37.5 \mathrm{x}^{2}, R^{2}=$ $0.83, P<0.01 ;$ cortex total $=1565.9-32.2 \mathrm{x}+$ $\left.15.9 \mathrm{x}^{2}, R^{2}=0.95, P<0.01\right)$. These patterns matched the patterns of ethylene production (Table 1).

Treatments reduced peel esters after harvest by $28 \%$ or greater in 2004 and by $32 \%$ or greater in 2005 (Table 2). By 6 and 12 weeks of cold storage in 2004, all the AVG and 1 -MCP treatments were recovering ester production to levels greater than controls, but AVG plus 1-MCP values were still low irrespective of harvest date or storage duration. In 2005, 1-MCP and the AVG plus 1-MCP treatments failed to recover ester production through 12 weeks of cold storage. Although considerably lower than the total ester levels, total alcohols showed the same general responses.

Six esters comprised nearly $90 \%$ of the total esters produced by control fruit peel tissue after harvest. These individual esters generally exhibited the same treatment
AVG plus 1-MCP reduced it in 2005. Peel AAT activity of AVG plus 1-MCP from H1 was greater than all other treatments but less than controls after 6 weeks in 2004, whereas no treatments differed from controls in 2005 . By 12 weeks all treatments reduced peel AAT, except for AVG from $\mathrm{H} 2$ in 2004, but AVG from $\mathrm{H} 1$ and $\mathrm{H} 2$ were greater than controls in 2005. Cortex AAT activity of treatments did not differ from controls in 2004 or 2005 at 6 weeks, or at 12 weeks in 2005, and only AVG from $\mathrm{H} 1$ and $\mathrm{H} 2$ were greater than controls at 12 weeks in 2004. Overall, the AVG plus 1-MCP reduced peel AAT activity compared with controls in 2004 but not in 2005. Because total peel ester production was reduced both years, this suggests that substrate levels were affected by the treatments and impacted total ester production.

Volatile substrate supplied. Peel and cortex tissue of control and AVG plus 1-MCPtreated fruit stored at $4{ }^{\circ} \mathrm{C}$ for 12 weeks were provided butanol or hexanol, and their ester production compared. Overall, total ester production (TEP) was higher from peel than cortex tissue. TEP of control fruit peel tissue not supplied with alcohol substrates was almost four times higher than from AVG plus 1-MCP-treated peel (Fig. 1), whereas there were no differences between the respective cortex tissues. TEP by peel of control versus AVG plus 1-MCP-treated samples were similar when they were provided with either butanol or hexanol. Control peel provided with hexanol had fivefold higher TEP than peel not supplied with hexanol. When provided butanol, control fruit cortex tissue had higher TEP than AVG plus 1-MCPtreated cortex, but TEP by cortex of control and treated fruit was similar when samples were provided with hexanol.

In the present study, control fruit were harvested at similar days after bloom, similar starch indices, and IEC levels close to 1 $\mu \mathrm{L} \cdot \mathrm{L}^{-1}$ in both years and were starting to ripen. In addition, control IEC increased significantly within $7 \mathrm{~d}$ at $21{ }^{\circ} \mathrm{C}$ both years (data not shown). Although harvested at similar days after full bloom and apparent physiological status both years, IEC responses to AVG and 1-MCP individually and to cold storage duration differed between the two seasons. This suggests that production environment or other preharvest factors also affected the fruit. The average temperature from bloom (20 Apr.) to harvest (15 Aug.) was $5^{\circ} \mathrm{C}$ higher in 2004 than in 2005 . The combined treatment exhibited the lowest IEC levels through 12 weeks across seasons, however (Table 1).

Irrespective of the differing patterns of control fruit IEC and TVP production between years, AVG plus 1-MCP generally had a greater and more consistent impact on both IEC and TVP than either alone after harvest and through 12 weeks of cold storage both seasons, although synergistic effects were not observed (Tables 1 and 2). AVG and 1-MCP alone have suppressed ethylene production and slowed ripening for varying 
periods of time after harvest and/or cold storage (Autio and Bramlage, 1982; DeLong et al., 2004; Drake et al., 2005, 2006; Fan et al., 1999; Johnson and Colgan, 2003; Mattheis et al., 2005; Moya-Leon et al., 2007; Rupasinghe et al., 2000; Schupp and Greene, 2004; Silverman et al., 2004), although their effects often diminished when used alone in the present work. The effects of 1-MCP diminished with storage time in 2004, and those of AVG did so in 2005. The combined treatment seemed to assure that ethylene and TVP were consistently suppressed.

Reduced TVP production by the AVG plus 1-MCP treatment was likely the result of substrate limitation, although AAT activity was also reduced in 2004. Ester synthesis can be limited by the concentration of substrates (Berger and Drawert, 1984; Echeverria et al., 2004). Peel and cortex tissues provided butanol or hexanol appeared capable of abundant volatile production (Fig. 1). Similar results from feeding precursors were observed after 1-MCP treatment alone (Ferenczi et al., 2006). Defilippi et al. (2005a, 2005b) indicated a clear regulation of AAT activity by ethylene, whereas alcohol dehydrogenase $(\mathrm{ADH})$ and lipoxygenase (LOX), which provide volatile precursors, were not. However, Da-Peng et al. (2006) observed a reduction in both $\mathrm{ADH}$ and LOX after 1-MCP treatment, indicating substrate levels may be altered. Total alcohol production recovered in most treatments in the present study, although AVG plus 1-MCP levels remained low, if not the lowest, through 12 weeks (Table 2).

Plotto et al. (1999) described a decrease in sensory scores for fruitiness of controlled atmosphere-stored 'Gala' apples that was correlated with a decrease in aroma volatile levels. At least some consumers may be able to distinguish 1-MCP-treated fruit by their low aroma volatile production (Marin et al., 2009). Because AVG plus 1-MCP repressed IEC and TVP the most, including key 'Gala' aroma volatiles, the treatment would negatively affect consumer acceptability. A longer period at $21{ }^{\circ} \mathrm{C}$ (Ferenczi et al., 2006), combined with sustained $\mathrm{C}_{2} \mathrm{H}_{4}$ treatment (Berger and Drawert, 1984; Fan et al., 1998; Johnson and Colgan, 2003), may be required for AVG plus 1-MCP-treated fruit to recover volatile production, although how the extended period and treatment may influence other quality traits would need to be determined.

\section{Literature Cited}

Argenta, L.C., M.J. Vieira, J.G. Krammes, J.L. Petri, and C. Basso. 2006. AVG and 1-MCP effects on maturity and quality of apple fruit at harvest and after storage. Acta Hort. 727:495-503.

Autio, W.R. and W.J. Bramlage. 1982. Effects of AVG on maturation, ripening and storage of apples. J. Amer. Soc. Hort. Sci. 107:1074-1077.

Baldwin, E.A. 2002. Fruit flavor, volatile metabolism and consumer perceptions, p. 89-106. In: Knee, M. (ed.). Fruits quality and its biological basis. Sheffield Academic Press Ltd., Sheffield, UK.

Bangerth, F. and J. Streif. 1987. Effect of aminoethoxyvinylglycine and low-pressure storage on the poststorage production of aroma vola- tiles by 'Golden Delicious' apples. J. Sci. Food Agr. 41:351-360.

Berger, R.G. and F. Drawert. 1984. Changes in the composition of volatiles by post-harvest application of alcohols to Red Delicious apples. J. Sci. Food Agr. 35:1318-1325.

Commercial Tree Fruit Spray Guide. 2006. Suggestions for growth regulators, p. 41-42. In: Bessin, R.T., R.T. Jones, J.G. Masabni, J.G. Strang, and J.R. Hartman (eds.). University of Kentucky Coop. Ext. Service, Lexington, KY.

Da-Peng, L., Y.-F. Xu, L.-P. Sun, L.-X. Liu, X.-L. Hu, D.-Q. Li, and H.-R. Shu. 2006. Salicylic acid, ethephon, and methyl jasmonate enhance ester regeneration in 1-MCP-treated apple fruit after long-term storage. J. Sci. Food Agr. 54:3887-3895.

Defilippi, B.G., A.A. Kader, and A.M. Dandekar. 2005a. Apple aroma: Alcohol acyltransferase, a rate limiting step for ester biosynthesis, is regulated by ethylene. Plant Sci. 168:1199-1210.

Defilippi, B.G., A.M. Dandekar, and A.A. Kader. 2005b. Relationship of ethylene biosynthesis to volatile production, related enzymes, and precursor availability in apple peel and cortex tissues. J. Agr. Food Chem. 53:3133-3141.

DeLong, J.M., R.K. Prange, and P.A. Harrison. 2004. The influence of 1-methylcyclopropene on 'Cortland' and 'McIntosh' apple quality following long-term storage. HortScience 39:1062-1065.

Drake, S.R., T.A. Eisele, D.C. Elfving, M.A. Drake, S.L. Drake, and D.B. Visser. 2005. Effects of the bioregulators aminoethoxyvinylglycine and ethephon on Brix, carbohydrates, acid, and mineral concentrations in 'Scarletspur Delicious' apple juice. HortScience 40:1421-1424.

Drake, S.R., D.C. Elfving, M.A. Drake, T.A. Eisele, S.L. Drake, and D.B. Visser. 2006. Effects of aminoethoxyvinylglycine, ethephon and 1-methylcyclopropene on apple fruit quality at harvest and after storage. HortTechnology 16:16-23.

Echeverria, G., T. Fuentes, J. Graell, I. Lara, and M.L. Lopez. 2004. Aroma volatile compounds of 'Fuji' apples in relation to harvest date and cold storage technology. A comparison of two seasons. Postharvest Biol. Technol. 32:29-44.

Fan, X., S.M. Blankenship, and J.P. Mattheis. 1999. 1-Methylcyclopropene inhibits apple ripening. J. Amer. Soc. Hort. Sci. 124:690-695.

Fan, X. and J.P. Mattheis. 1999. Impact of 1methylcyclopropene and methyl jasmonate on apple volatile production. J. Agr. Food Chem. 47:2847-2853.

Fan, X., J.P. Mattheis, and D. Buchanan. 1998 Continuous requirement of ethylene for apple fruit volatile synthesis. J. Agr. Food Chem. 46:1959-1963.

Ferenczi, A., J. Song, M. Tian, K. Vlanchonasios, D. Dilley, and R. Beaudry. 2006. Volatile ester suppression and recovery following 1methylcyclopropene application to apple fruit. J. Amer. Soc. Hort. Sci. 131:691-701.

Greene, D.W. 2006. An update on preharvest drop control of apples with aminoethoxyvinylglycine (ReTain). Acta Hort. 727:311-319.

Greene, D.W. and J.R. Schupp. 2004. Effect of aminoethoxyvinylglycine (AVG) on Preharvest drop, fruit quality, and maturation of 'McIntosh' apples. II. Effect of timing and concentration relationships and spray volume. HortScience 39:1036-1041.

Halder-Doll, H. and F. Bangerth. 1987. Inhibition of autocatalytic $\mathrm{C}_{2} \mathrm{H}_{4}$ biosynthesis by AVG applications and consequences on the physiological behavior and quality of apple fruits in cold storage. Scientia Hort. 33:87-96.
Hamilton-Kemp, T.R., D.D. Archbold, K. Yu, and R.W. Collins. 2003. Emission patterns of wound volatile compounds following injury of ripe strawberry fruit. J. Sci. Food Agr. 83:283-288.

Johnson, D.S. and R.J. Colgan. 2003. Low ethylene controlled atmosphere induces adverse effects on the quality of 'Cox's Orange Pippin' apples treated with aminoethoxyvinylglycine during fruit development. Postharvest Biol. Technol. 27:59-68.

Kondo, S., S. Setha, D.R. Rudell, D.A. Buchanan, and J.P. Mattheis. 2005. Aroma volatile biosynthesis in apples affected by 1-MCP and methyl jasmonate. Postharvest Biol. Technol. 36:61-68.

Lurie, S., C. Pre-Aymard, U. Ravid, O. Larkov, and E. Fallik. 2002. Effect of 1-methylcyclopropene on volatile emission and aroma in cv. Anna apples. J. Agr. Food Chem. 50:4251-4256.

Marin, A.B., A.E. Colonna, K. Kudo, E.M. Kupferman, and J.P. Mattheis. 2009. Measuring consumer response to 'Gala' apples treated with 1-methylcyclopropene. Postharvest Biol. Technol. 51:73-79.

Mattheis, J.P., X. Fan, and L.C. Argenta. 2005. Interactive responses of Gala apple fruit volatile production to controlled atmosphere storage and chemical inhibition of ethylene action. J. Agr. Food Chem. 53:4510-4516.

Mir, N.A., R. Perez, P. Schwallier, and R. Beaudry. 1999. Relationship between ethylene response manipulation and volatile production in Jonagold variety apples. J. Agr. Food Chem. 47: 2653-2659.

Moran, R.E. 2006. Maintaining fruit firmness of 'McIntosh' and 'Cortland' apples with aminoethoxyvinylglycine and 1-methylcyclopropene during storage. HortTechnology 16:513-516.

Moya-Leon, M.A., M. Vergara, C. Bravo, M. Pereira, and C. Moggia. 2007. Development of aroma compounds and sensory quality of 'Royal Gala' apples during storage. J. Hort. Sci. Biotechnol. 83:403-413.

Paillard, N.M. 1990. The flavour of apples, pears and quinces, p. 1-41. In: Morton, I.D. and J. McLeod (eds.). Food favours, Part C. The flavour of fruits. Elsevier Science Publishing Company Inc., Amsterdam, The Netherlands.

Plotto, A., M.R. McDaniel, and J.P. Mattheis. 1999. Characterization of 'Gala' apple aroma and flavor: Differences between controlled atmosphere and air storage. J. Amer. Soc. Hort. Sci. 124:416-423.

Plotto, A., M.R. McDaniel, and J.P. Mattheis. 2000. Characterization in changes in 'Gala' apple aroma during storage using osme analysis, a gas chromatography-olfactometry technique. J. Amer. Soc. Hort. Sci. 125:714-722.

Robinson, T.L., C.B. Watkins, S.A. Hoying, J.F. Nock, and K.I. Iungerman. 2006. Aminoethoxyvinylglycine and 1-methylcyclopropene effects on 'McIntosh' preharvest fruit drop, fruit maturation and fruit quality after storage. Acta Hort. 727:473-480

Rupasinghe, H.P., D.P. Murr, G. Paliyath, and L. Skog. 2000. Inhibitory effect of $1-\mathrm{MCP}$ on ripening and superficial scald development in 'McIntosh' and 'Delicious' apples. J. Hort. Sci. Biotechnol. 75:271-276.

Schupp, J.R. and D.W. Greene. 2004. Effect of aminoethoxyvinylglycine (AVG) on preharvest drop, fruit quality, and maturation of 'McIntosh' apples. I. Concentration and timing of dilute applications of AVG. HortScience 39:1030-1035.

Silverman, S.P., P.D. Petracek, M.R. Noll, and P. Warrior. 2004. Aminoethoxyvinylglycine effects on late-season apple fruit maturation. Plant Growth Regulat. 43:153-161. 